\title{
MAGT1 Deficiency
}

National Cancer Institute

\section{Source}

National Cancer Institute. MAGT1 Deficiency. NCI Thesaurus. Code C126336.

A condition of decreased or absent presence or activity of magnesium transporter 1 protein. Deficiency of this protein is associated with X-linked immunodeficiency with magnesium defect, Epstein-Barr virus infection, and neoplasia (XMEN). 